In Submerged Landscapes of the European Continental Shelf: Quaternary Paleoenvironments. Chap. 17. pp 479-495

2017

Eds Nicholas C. Flemming, Jan Harff, Delminda Moura, Anthony

Burgess, Geoffrey N. Bailey

ISBN 9781118922132

http://dx.doi.org/10.1002/9781118927823.ch17

http://archimer.ifremer.fr/doc/00391/50264/

(c) 2017 John Wiley \& Sons, Ltd. All rights reserved.

\title{
Late Pleistocene Environmental Factors defining the Black Sea, and Submerged Landscapes on the Western Continental Shelf
}

\author{
Lericolais Gilles $^{1}$ \\ ${ }^{1}$ IFREMER, DAEI, Issy-les-Moulineaux, France
}

\begin{abstract}
:
The Black Sea semi-enclosed basin is bounded by Europe, Asia Minor and the Caucasus and is ultimately connected to the Atlantic Ocean via the Mediterranean and Aegean seas and various straits. The Bosporus Strait connects it to the Sea of Marmara, and the Dardanelles Strait connects it to the Aegean Sea region of the Mediterranean. For about 15 years the sedimentary systems of the northwestern part of the Black Sea extending from the continental shelf and slope down to the deep-sea zone have been studied using geophysical and coring techniques. These results provide a robust record of water-level fluctuations in the Black Sea since the Last Glacial Maximum (LGM) and thereby shed new light on its disputed aspects. The deep-sea fan studies demonstrate that the last channel-levee system on the Danube fan developed during the LGM with a water level about $120 \mathrm{~m}$ lower than today
\end{abstract}

Keywords : Black Sea basin, Late Pleistocene environmental factors, marine sedimentology research, submerged landscapes, water-level fluctuation, western continental shelf 


\section{Introduction}

he Black Sea semi-enclosed basin (Fig. 17.1) is bounded by Europe, Asia Minor and the Caucasus and is ultimately connected to the Atlantic Ocean via the Mediterranean and Aegean seas and various straits. The Bosporus Strait connects it to the Sea of Marmara, and the Dardanelles Strait connects it to the Aegean Sea region of the Mediterranean. These waters separate eastern Europe and western Asia. The Black Sea also connects to the Sea of Azov by the Kerch Strait (see Chapter 16, pas [ [ Black Sea water-level fluctuations are directly linked to changes in climate, river input and the balance between evaporation and precipitation, without any hysteresis effect compared to the Global Ocean (see discussion of sea level in Chapter 2, pages [

As a consequence of such fundamental climatic changes, there were modifications of landscapes and ecosystems extending into the Carpathian-DanubianPontian space, and corresponding adaptations by the human inhabitants. These changes were especially marked during the Epipaleolithic and Neolithic periods, associated with the final hunter-gatherer populations of the region and the spread of agriculture. Domestication of crops and animals is thought to have started in the
Au: Please provide page no. in $[\mathbf{x x x}]$ through-out 


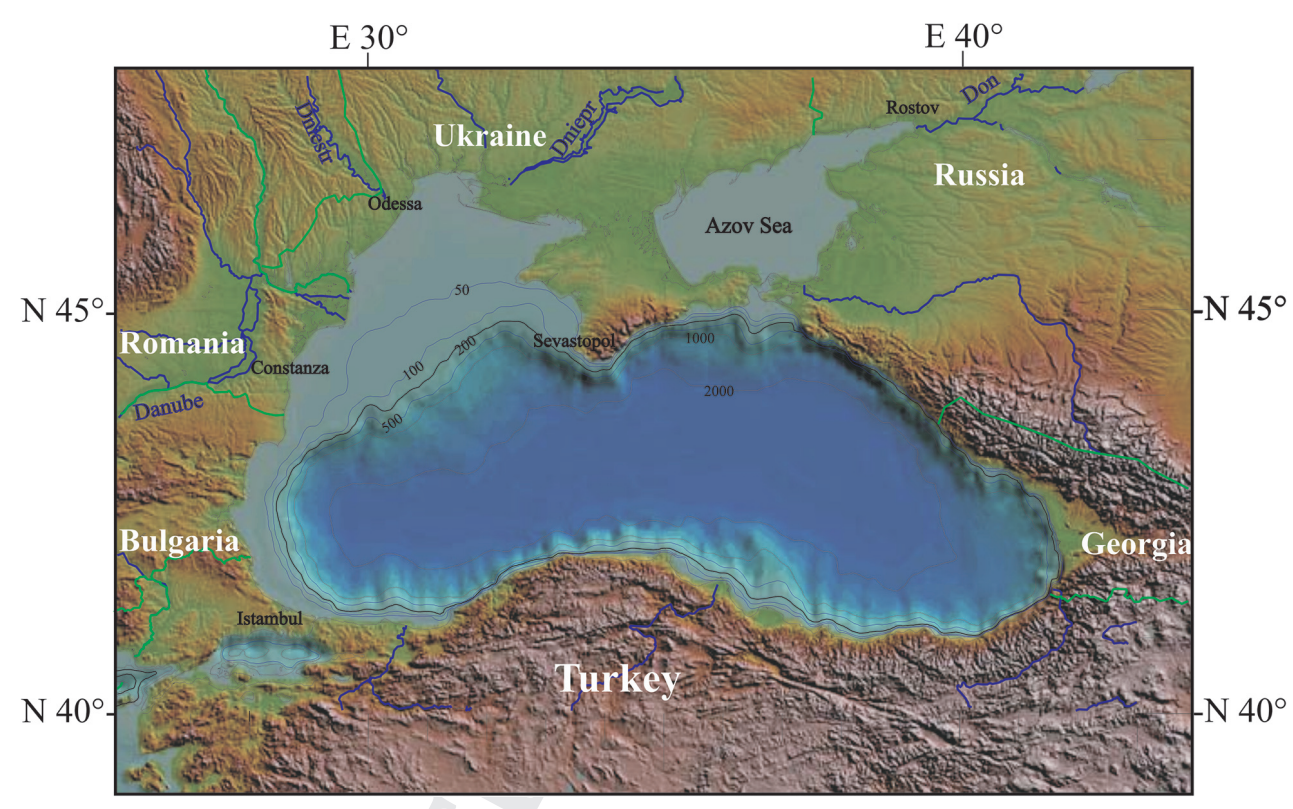

Fig. 17.1 Regional situation of the Black Sea showing simplified bathymetry, neighboring countries, and main river inputs.

Near East around 11,000 BP with a spread to Anatolia and the southern part of the Black Sea by about 10,000 BP (Ivanov \& Avramova 2000).

The northwestern Black Sea shelf (Fig. 17.1) has been exposed as much as the European shelves were during sea-level lowstands, but with a regionally distinct timing due to the isolation of the basin. This now-submerged Black Sea shelf probably provided a crucial arena for the survival and dispersal of some of Europe's earliest inhabitants during the Stone Age, the early development of prehistoric societies, the initial spread of agriculture from the Near East, and the foundations for the earliest civilizations. The oldest hominin archaeological site outside Africa is located in Georgia, $200 \mathrm{~km}$ inland from the Black Sea coast at Dmanisi (see for example Lordkipanidze et al. (2013) for descriptions of skull remains about 1.89 million years old at this site). Much of the key evidence relating to these Pleistocene developments during multiple glaciations now lies buried on the sea floor. However, the water-level fluctuations of the Black Sea behaved independently from the global sea level during its period of disconnection from the Global Ocean in successive glaciations. In the aftermath of the last ice age, water levels in the Black Sea and the Aegean Sea rose independently until they were high enough to exchange water over the Bosporus sill. The exact timeline of this development has been subject to debate until recent dating of the re-connection obtained by Soulet et al. (2011b) based upon modeling experiments and micropaleontological reconstructions. For these authors, the Black Sea 'Lake' reconnection occurred in two steps, as follows: 1) Initial Marine Inflow (IMI) dated at 9000 cal BP followed by 2) a period of increasing basin salinity that led to the Disappearance of Lacustrine Species (DLS), a process lasting between 900 and 1000 years after the first reconnection, as also confirmed by Nicholas et al. (2011).

\section{Regional Geology of the Black Sea Basin}

The Black Sea is a land-locked basin, located between Europe and Asia Minor. It is generally considered to be the result of a back-arc extension associated with Mesozoic northward subduction of the Tethys Ocean beneath the Eurasian continent (Letouzey et al. 1978; Zonenshain \& Pichon 1986; Finetti et al. 1988; Okay et al. 1994). At the end of the Eocene, the paleogeographic reorganization stemming from the closure of the 
Tethys, and the associated collision of continental blocks, resulted in the individualization of two new sedimentary realms on both sides of the Alpine orogenic belts: the Mediterranean Sea to the south, and the Paratethys to the north. The wide intracontinental Paratethys Sea extended through central Europe from the western Alpine foredeeps, toward the Aral Sea in Asia (Steininger \& Papp 1979). Its present remnants are the French Rhône and Swiss Molasse basins (western Paratethys), the Pannonian basin (central Paratethys), the Dacian, the Euxinic (i.e. Black Sea) (Fig. 17.1) and the Aralo-Caspian basins (eastern Paratethys). The Late Eocene to Middle Miocene paleoenvironmental and paleogeographical evolution of the Paratethys was characterized by a long-term trend of decreasing marine influence and a correlated reduction in size of the sedimentation domains, both resulting from the Alpine orogenic activity (Rögl 1999; Meulenkamp \& Sissingh 2003). After the Middle Miocene, Paratethyan conditions evolved into drastically restricted marine environments (Fig. 17.2).
This paleogeographical reshaping culminated in overall uplift around Paratethys, leading to the progressive isolation, dislocation and, during the Pliocene, to the final infilling of most of the western Paratethyan basins (Meulenkamp \& Sissingh 2003). This Neogene evolution was characterized by several successive closure episodes of the Paratethys marine connections towards the Mediterranean Sea and Indian Ocean (Rögl 1999; Meulenkamp \& Sissingh 2003). On the one hand, severance of these connections resulted in the development of largely endemic faunas and floras which led to the establishment of specific Neogene stratigraphic scales for the Paratethyan sub-basins (Papp et al. 1974; Papaianopol \& Marinescu 1995; Rögl 1998; Chumakov 2000). On the other hand, the episodic closures of the open seaways led to potential eustatic responses within the isolated basins. Depending on the hydraulic budget of the basin, its base level would evolve toward two main tendencies during isolation phases: either a positive hydraulic budget with a rapid rise in water, or a negative hydraulic budget with a

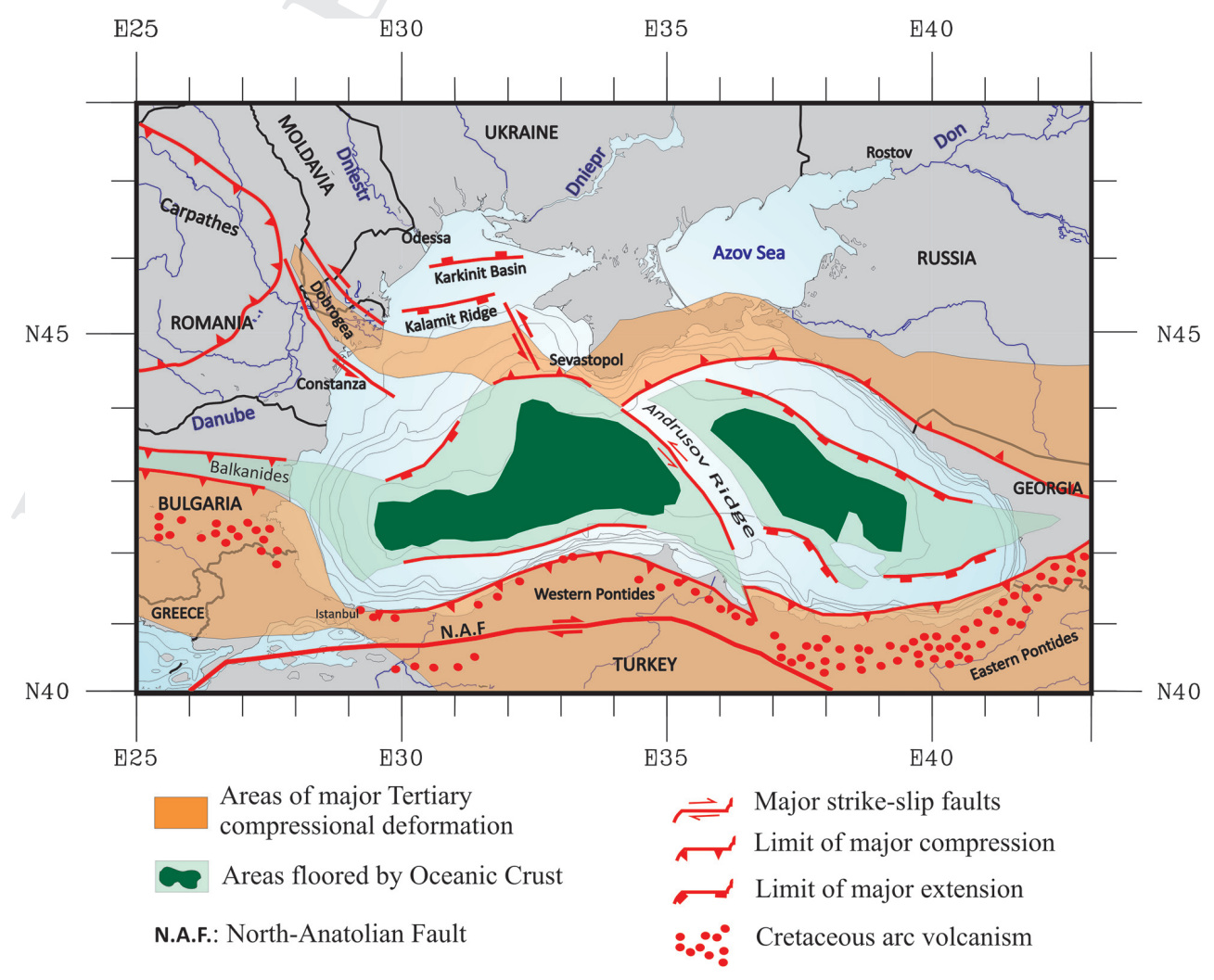

Fig. 17.2 Black Sea solid geology. After Dinu et al. (2002). 
drastic fall in level. Because the basins have relatively small superficial areas, these eustatic responses could reach large amplitudes in a very short time. In the Late Miocene, just before the Messinian Salinity Crisis in the Mediterranean Sea (Hsü et al. 1973), the eastern Paratethys, including the Black Sea and Dacic basin, was connected to the Mediterranean realm by a shallow sill north of the Aegean Sea (Rögl 1999; Meulenkamp \& Sissingh 2003). Presence of such a connection is supported by the influx of Mediterranean fauna (NN11) recorded in the Dacic basin (Mărunţeanu 1992; Clauzon et al. 2005). With regard to this paleogeographical situation, it has been proposed that the Mediterranean Messinian Salinity Crisis resulted in complete isolation of the eastern Paratethys.

\section{Bathymetry and High Resolution Data}

Global bathymetry of the Black Sea can be obtained through the International Bathymetric Chart of the Mediterranean (IBCM), which is an intergovernmental project created to produce regional-scale bathymetric maps and data sets, together with geological/geophysical overlays, of the Mediterranean region including the Black Sea (Fig. 17.2). Sponsorship of the IBCM project comes from the Intergovernmental Oceanographic Commission (IOC), a branch of UNESCO. As seafloor bathymetric data acquired with modern swath echo sounders provide coverage for only a small fraction of the global seabed, new global composite bathymetry has been built up. In 2009, a method for compilation of global seafloor bathymetry that preserves the inherent resolution of swath sonar raw data was published by Ryan et al. (2009). This Global Multi-Resolution Topography synthesis consists of a hierarchy of tiles with digital elevations and shaded relief imagery spanning nine magnification doublings from pole-to-pole (www.marine-geo.org/ portals/gmrt). The compilation is updated and accessible as surveys are contributed, edited, and added to the tiles. Access to the bathymetry tiles is via web services and with WMS-enabled client applications such as GeoMapApp, Virtual Ocean, NASA World Wind, and Google Earth (Ryan et al. 2009). More recently the FES2012 project from the Laboratoire d'Etudes en Géophysique et Océanographie Spatiales (LEGOS, Toulouse France) built a composite bathymetry based on ETOPO1 (Amante \& Eakins 2009) and on a 1-km grid of a morpho-bathymetric map of the Mediterranean Sea derived from multibeam swath sonar surveys provided to the National Geophysical Data Center (NGDC) by Benoit Loubrieu (Institut Français de Recherche pour l'Exploitation de la Mer - IFREMER) and published and promoted by the Commission Internationale pour l'Exploration Scientifique de la mer Méditerranée (CIESM) (Loubrieu et al. 2008). Patches are then performed to update the original bathymetry with the most accurate local depths (or those believed to be so). Details on global and regional databases can be found on the LEGOS bathymetry database web page. All global databases have been updated before patching (www. legos.obs-mip.fr/recherches/equipes/ecola/projets/fes 2012 /bathymetry).

Here, part of the data used in the CIESM map was acquired in the Black Sea by the ASSEMBLAGE 5th European Project. Acquisition and reduction of multibeam bathymetry and imagery data sets were carried out to determine the sediment deposited since the last sea-level rise. Construction of Digital Terrain Models (DTM) of the bathymetry were generated to produce major maps of the western part of the Black Sea (Fig. 17.3).

\section{Marine Sedimentology Research}

For about 15 years the sedimentary systems of the northwestern part of the Black Sea extending from the continental shelf and slope down to the deep-sea zone have been studied using geophysical and coring techniques. These results (Popescu et al. 2001; 2004; Lericolais et al. 2007a,b; 2009; 2011; Popescu \& Lericolais 2009; Soulet et al. 2010; 2011a,b; 2013) provide a robust record of water-level fluctuations in the Black Sea since the Last Glacial Maximum (LGM) and thereby shed new light on its disputed aspects. Recently, a wide range of work carried out in the Black Sea attempted to assess 


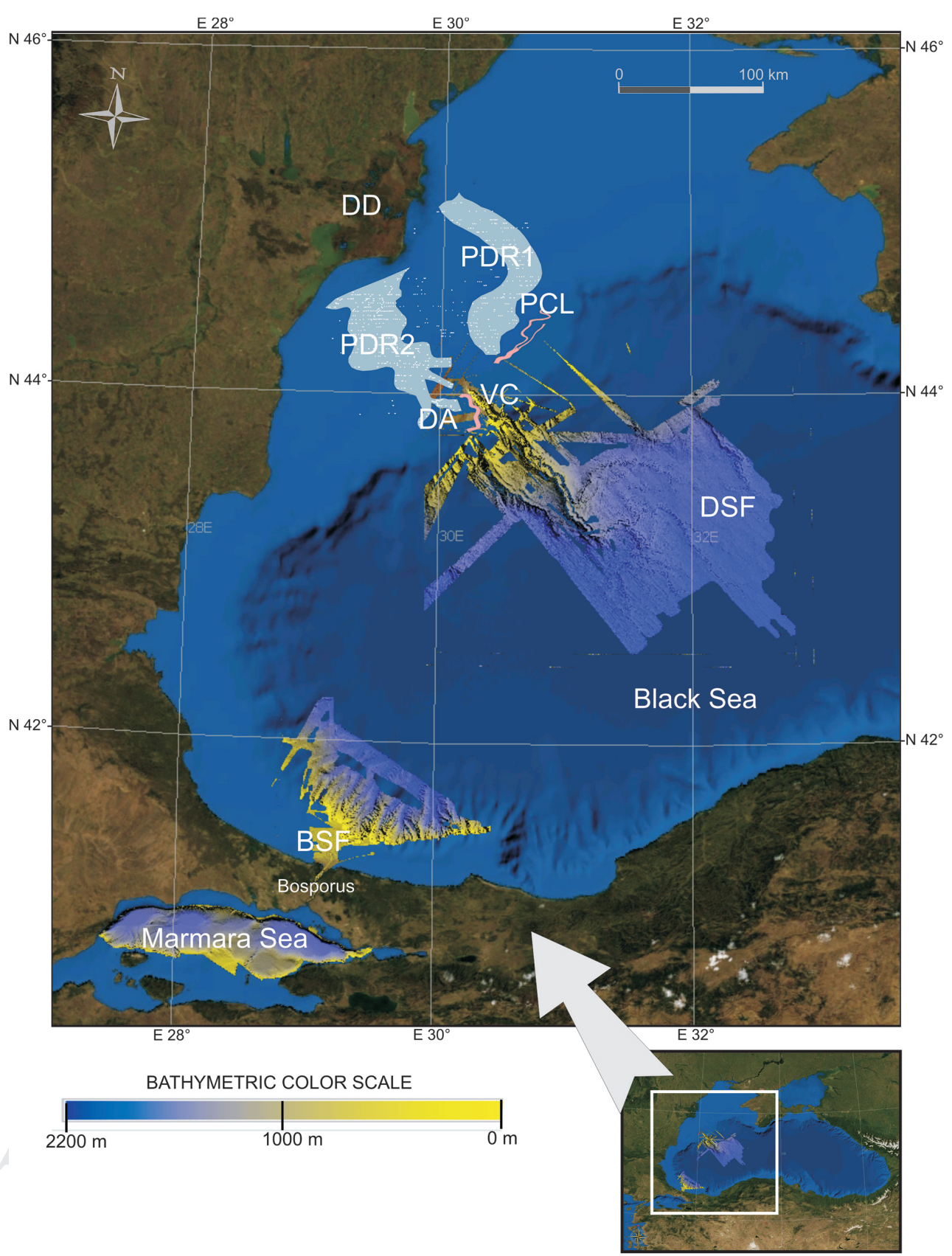

Fig. 17.3 Western Black Sea shelf presenting the location map of the geomorphological interpretation resulting from previous work. Popescu et al. (2001; 2004); Lericolais et al. (2007a). DD = Danube Delta; PCL = Paleocoastline; PDR1 = Paleo-Danube River 1; PDR2 = Paleo-Danube River 2; DA = Dunes area; VC = Viteaz canyon; DSF = Deep-sea fan; BSF = Bosporus-shelf fan.

the last cycle of sea-level rise, and provide scenarios to assist in quantifying the processes governing the transition from a low-salinity to a marine state while also addressing the variability expressed by this system (see also
Chapter 16, pages [ were established prior to reconstructing the Black Sea water-level fluctuations since the LGM (Lericolais et al. 2011). 
The existence of a LGM lowstand wedge at the shelf edge off the coasts of Romania, Bulgaria and Turkey (Lericolais et al. 2011). This observation includes evidence of a second small lowstand wedge dated between 12,000 cal BP and $9000 \mathrm{cal} \mathrm{BP}$ at water depths from $100 \mathrm{~m}$ to $120 \mathrm{~m}$, identified during ASSEMBLAGE cruises on the outer shelf of Romania and Bulgaria (Lericolais et al. 2007a,b; 2009; 2011), and described on the Turkish shelf by Algan et al. (2002). This wedge is associated with the recovery of strata immediately below an observed unconformity consisting of dense mud with low water content, and containing desiccation cracks, plant roots, and sand lenses rich in freshwater mollusks (Dreissena rostriformis) with both valves still joined together.

Information on the building of the Danube Delta/prodelta, showing that a former pro-delta built up at -40 $\mathrm{m}$ after the post-LGM meltwater pulses.

Mapping of meandering river channels capped by a regional unconformity, and extending seaward across the Romanian shelf to the vicinity of the $-100 \mathrm{~m}$ isobath.

The presence of submerged shorelines with wave-cut terraces and coastal dunes, or delta mouth bars at depths between $80 \mathrm{~m}$ to $100 \mathrm{~m}$ below the Holocene Bosporus and Dardanelles Strait outlet sill to the Global Ocean.

Evidence on the western part of the Black Sea continental shelf of a shelf-wide ravinement surface, visible in highto very-high-resolution seismic reflection profiles.

The presence of a uniform drape of sediment beginning at the same time above the unconformity, with practically the same thickness over nearby elevations and depressions and with no visible indication of coastal-directed onlap across the outer and middle shelf, except in the vicinity of the Danube Delta where this mud drape is overlapped by recent Danube sediments.

These critical factors enable quantification of the processes governing the transition from a semi-freshwater lake to a marine state and a better understanding of the last sea-level rise in the Black Sea. The scenario starts at the LGM about 21,000 years ago, when the Black
Sea was probably a giant freshwater lake (Soulet et al. 2010).

\section{Post-LGM Climate, Sea Level, and Paleoshorelines}

\section{Water-level fluctuation scenario}

The deep-sea fan studies (Popescu et al. 2001; Lericolais et al. 2012; 2013) demonstrate that the last channel-levée system on the Danube fan developed during the LGM with a water level about $120 \mathrm{~m}$ lower than today. The proximity of the Scandinavian-Russian ice cap supplied glacial melt water into the Black Sea through the major drainage system of the larger European rivers (Danube, Dnieper, Dniester, and Bug), and this is registered as brownish layers identifiable in cores (Fig. 17.4) (Major et al. 2002a; Bahr et al. 2005; Soulet et al. 2013). The volume of water brought to the Black Sea after Meltwater Pulse 1A (MWP-1A) at approximately $14,500 \mathrm{cal} \mathrm{BP}$ (Soulet et al. 2011b) was sufficient to raise the water level from $-40 \mathrm{~m}$ to $-20 \mathrm{~m}$. The $-40 \mathrm{~m}$ limit has been

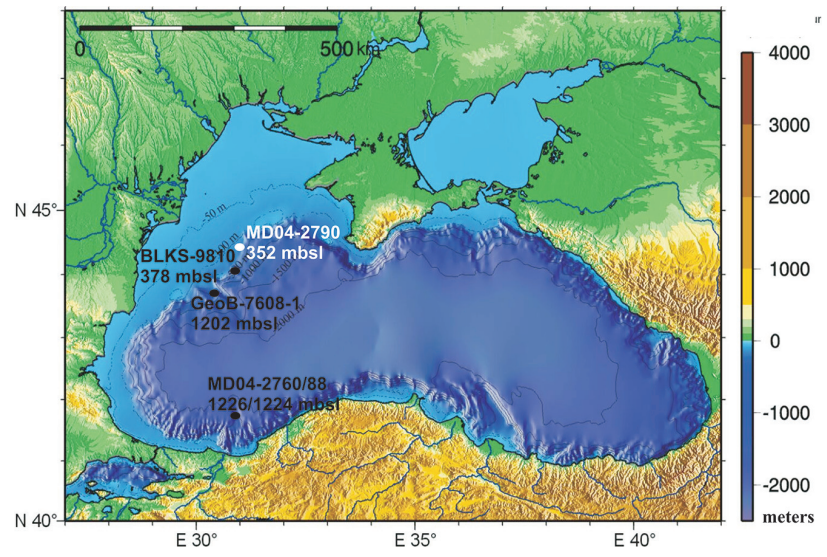

Fig. 17.4 Location of the cores used by Soulet et al. (2011a). The white dot indicates the location of the MD04 2790 coring site (44 12.8 N, 3059.6 E) studied by Soulet et al. (2011a). Black dots represent the coring locations for previously published cores as follows: BLKS-9810 (Major et al. 2002b); GeoB 7608-1 (Bahr et al. 2005); and MD04-2760 and MD04-2788 (Kwiecien et al. 2008). The coring depths, in meters below sea level (MBSL), are indicated below the coring sites. 
inferred from the Danube prodelta building (Lericolais et al. 2009), but this is not definitive and Yanko (1990) gives evidence for the $-20 \mathrm{~m}$ limit. This last value for the transgression's upper limit would have brought the level of the Black Sea even higher in relation to the Bosporus sill, with a possible influx of marine species, such as Mediterranean dinoflagellates (Popescu 2004). Nevertheless, the rise in the water level of the Black Sea, which maintained fresh to brackish conditions, stopped deep-sea fan sedimentation.

Palynological studies conducted on BlaSON cores (Fig. 17.4) (Popescu 2004) show that, from the Bølling/Allerød to the Younger Dryas (i.e. from $14.7 \mathrm{ka}$ to $12.7 \mathrm{ka}$ ), a cooler and drier climate prevailed. The flow from northeastern European rivers converged into the North Sea and the Baltic Ice Lake (Jensen et al. 1999), resulting in reduced river input to the Black Sea and a receding shoreline. These observations are consistent with an evaporative drawdown of the Black Sea and correlate with evidence of an authigenic aragonite layer present in all the cores studied (Strechie et al. 2002; Giunta et al. 2007). This drawdown is also confirmed by the forced regression-like reflectors recognized on the dune field mosaics (Lericolais et al. 2009). The presence of coastal sand dunes and wave-cut terraces confirms this lowstand. This had already been observed by several Russian authors, who considered a sea-level lowstand at about $90 \mathrm{~m}$ depth. Their observations were based on the location of offshore sand ridges described at the shelf edge south of Crimea. Around the Viteaz canyon (Danube canyon), the paleocoastline was forming a wide gulf in which two rivers (PDR1 and 2) were flowing (Fig. 17.3). Earlier studies had already proposed a depth of $105 \mathrm{~m}$ for this lowstand according to a regional erosional truncation recognized on the southern coast of the Black Sea (Demirbağ et al. 1999; Görür et al. 2001), but also based on the presence of a terrace on the northern shelf edge (Major et al. 2002b; Lericolais et al. 2007a).

On the Romanian shelf, preservation of sand dunes and small, buried incised valleys can be linked to a rapid transgression during which the ravinement processes related to water-level rise had insufficient time to erode the sea bottom to any substantial extent (Ahmed Benan \& Kocurek 2000; Lericolais et al. 2004). Around $9000 \mathrm{cal}$
$\mathrm{BP}$, the surface waters of the Black Sea suddenly attained present-day conditions owing to an abrupt flooding of the Black Sea by Mediterranean waters, as shown by dinoflagellate cyst records (Popescu 2004) and recently demonstrated by Soulet et al. (2011b) and Nicholas et al. (2011). The inflow of marine water is confirmed by the abrupt replacement of fresh-to-brackish species by marine species. Furthermore, Soulet et al. (2011b) and Nicholas et al. (2011) demonstrate that the Black Sea 'Lake' reconnection occurred in two steps, with an Initial Marine Inflow (IMI) dated at $9000 \mathrm{cal} \mathrm{BP}$, followed by a ca. 1000-year period of increasing basin salinity (as noted above in the Introduction, pas $[$ a event can also be related to the beginning of the sapropel deposit which is widespread and synchronous across the basin slope and floor. The Black Sea basin would have been flooded in $\sim 1000$ years, equalizing water levels in the Black Sea and Sea of Marmara. Such a sudden flood at a rate of about $10 \mathrm{~m}$ per century would have preserved lowstand coastal marks on the Black Sea's northwestern shelf.

From these syntheses, the water-level fluctuation diagram proposed (Fig. 17.5) is judged to be the one that best fits the recently published observations.

\section{Discussion of sea-level curve and its archaeological implications}

Many decades of work carried out by scientists from Russia and other eastern European countries (Andrusov 1893; Yaranov 1938; Nevesskiy 1961; Fedorov 1963; Kvasov 1968; Muratov et al. 1974; Ostrovskiy et al. 1977; Arslanov et al. 1978; Shimkus et al. 1980; Balabanov 1984) led to the publication of different hypotheses and curves for Holocene sea-level changes in the Black Sea. Using these different works a first synthesis effort was produced by Pirazzoli (1991). However, Ryan et al. (1997) published a hypothesis according to which a massive flood through the Bosporus occurred in ancient times. They claim that the Black Sea was a vast freshwater lake, but then about 7500 BP, later corrected to 8400 BP (Ryan et al. 2003; Ryan 2007), the Mediterranean spilled over a sill at the Bosporus, creating the current communication between the Black and Mediterranean seas. Subsequent work has 

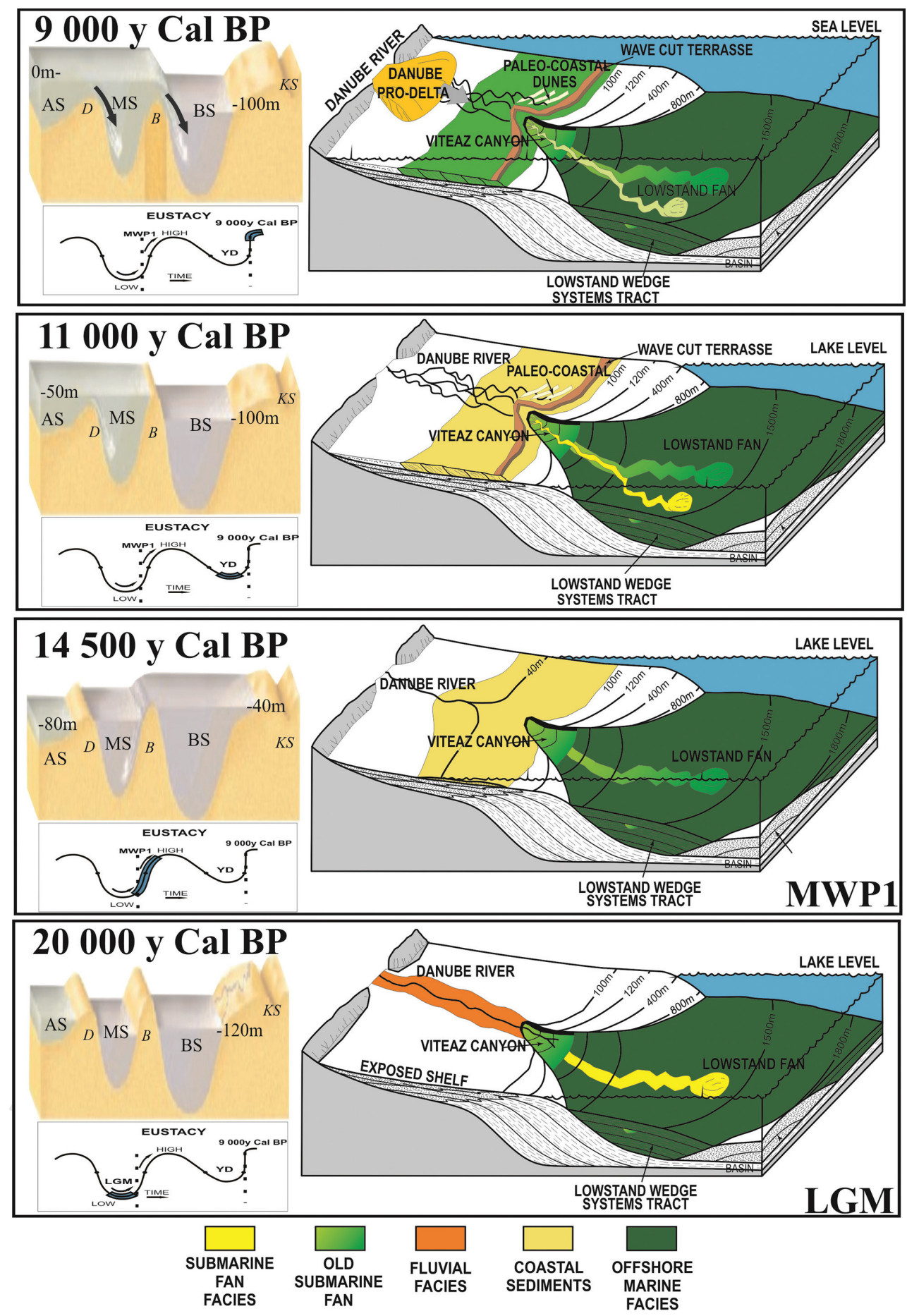

Fig. 17.5 Modified from Lericolais et al. (2009), where dates were calibrated using IntCAL09 with Soulet et al. (2011b) work and reservoir ages. The schematic scenario is inspired by Posamentier and Vail (1988) and shows water-level fluctuation in the Black Sea since the LGM, deduced from geomorphological results, supported by the Danube deep-sea fan functioning (Popescu et al. 2001), the results from palynology and dinoflagellates (Popescu et al. 2004) and the paleocoastline position. 
both supported and discredited this hypothesis, and it is still a matter of active debate (Aksu et al. 1999; 2002; Ballard et al. 2000; Kerr 2000; Uchupi \& Ross 2000; Görür et al. 2001; Major et al. 2002b; 2006; Ryan et al. 2003; Algan et al. 2007; Balabanov 2007; Hiscott et al. 2007; Giosan et al. 2009; Lericolais et al. 2009; 2010). Such a late reconnection would lead to a longer exposure of the Black Sea shelf allowing human settlements to become established near the coast. This has led some to associate the supposedly catastrophic flooding of the shelf with prehistoric flood myths, and this has become one of the most visible scientific debates of recent years, and one that has fascinated the public imagination.

This controversy was one of the triggers for the installation of IGCP (International Geoscience Programme) Project 521 'Black Sea-Mediterranean Corridor during the last 30 ky: sea level change and human adaptation'. The resulting book edited by Yanko-Hombach et al. (2007) is a good record of the state of research from geology to archaeology carried out in the Black Sea. However, many conclusions of studies presented in the volume should be considered cautiously as it is evident that a vigorous debate is ongoing and much research remains to be done (see also Chapter 16, [pages [xxy $[\mathrm{xxx}]$ ).

Recent studies supported by the European Commission (described above) led to a synthesis on the assessment of the last sea-level rise in the Black Sea obtained from observations collected by a series of expeditions carried out between 1998 to 2005, in particular, the evidence of recent submerged landscapes, the erosion of which was due to wave action around $9000 \mathrm{cal} \mathrm{BP}$ (Soulet et al. 2011b). Based on these results, a sea-level curve was first published in 2009 by Lericolais et al. (2009). This curve (Fig. 17.6) is here adapted using recent calibration of radiocarbon dates (Soulet et al. 2011b). Before these important results, numerous Russian authors indicated a sea-level lowstand at about $90 \mathrm{~m}$ depth, based on the location of offshore sand ridges described at the shelf edge south of Crimea. The unique wave-cut terrace on the outer Romanian shelf presenting an upper surface varying between $-95 \mathrm{~m}$ and $-100 \mathrm{~m}$ is therefore consistent with a major lowstand level situated somewhere around $100 \mathrm{~m}$ depth and evidence that the Black Sea shelf had emerged at the beginning of the Holocene.

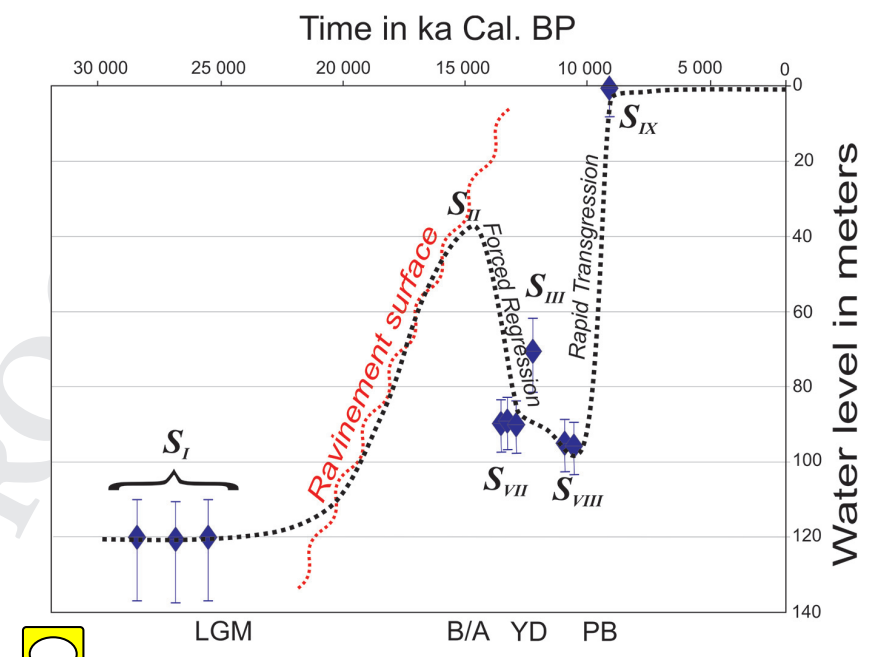

FIg. 17.6 Water-level fluctuation in the Black Sea since the Last Glacial Maximum. LGM = Last Glacial Maximum; B/A = Bølling/Allerød; YD = Younger Dryas; $\mathrm{PB}=$ Pre-Boreal. $\mathrm{S}_{\mathrm{I}}$ to $\mathrm{S}_{\mathrm{IX}}$ are the sequences interpreted and dated from the Romanian Black Sea shelf. This figure is published in Lericolais et al. (2009).

\section{Modern Coastline and Coastal Processes: the Danube Delta}

Before entering the Black Sea, the Danube forms a wide, branching delta, the second largest river delta in Europe. It is located between longitude E28 $45^{\prime}$ and E29 46 and latitude $\mathrm{N} 44^{\circ} 25^{\prime}$ and $\mathrm{N} 45^{\circ} 37^{\prime}$ covering a surface of almost $5800 \mathrm{~km}^{2}$ (Fig. 17.3 'DD'), confined by the Bugeac Plateau to the north and by the Dobrogea region to the south (Panin 1996). The development of the delta starts at the point where the Danube River's main channel divides into three main branches: the northern Chilia, the central Sulina and the southern St. George (Sfântu Gheorghe). A mosaic of shallow lakes and channels, fringed by reeds, lies between these branches. The Danube Delta is classified as a fluvial-dominated delta starting in a Black Sea embayment sheltered by a barrier (Panin 1983). After reaching the coast, the three main branches of the Danube Delta constitute four laterally offset lobes. Opencoast delta lobes are wave-dominated (Fig. 17.7), with the exception of Chilia III, the youngest lobe, which has a primarily fluvial-dominated morphology (Giosan et al. 2006). The wave-dominated lobes exhibit an 


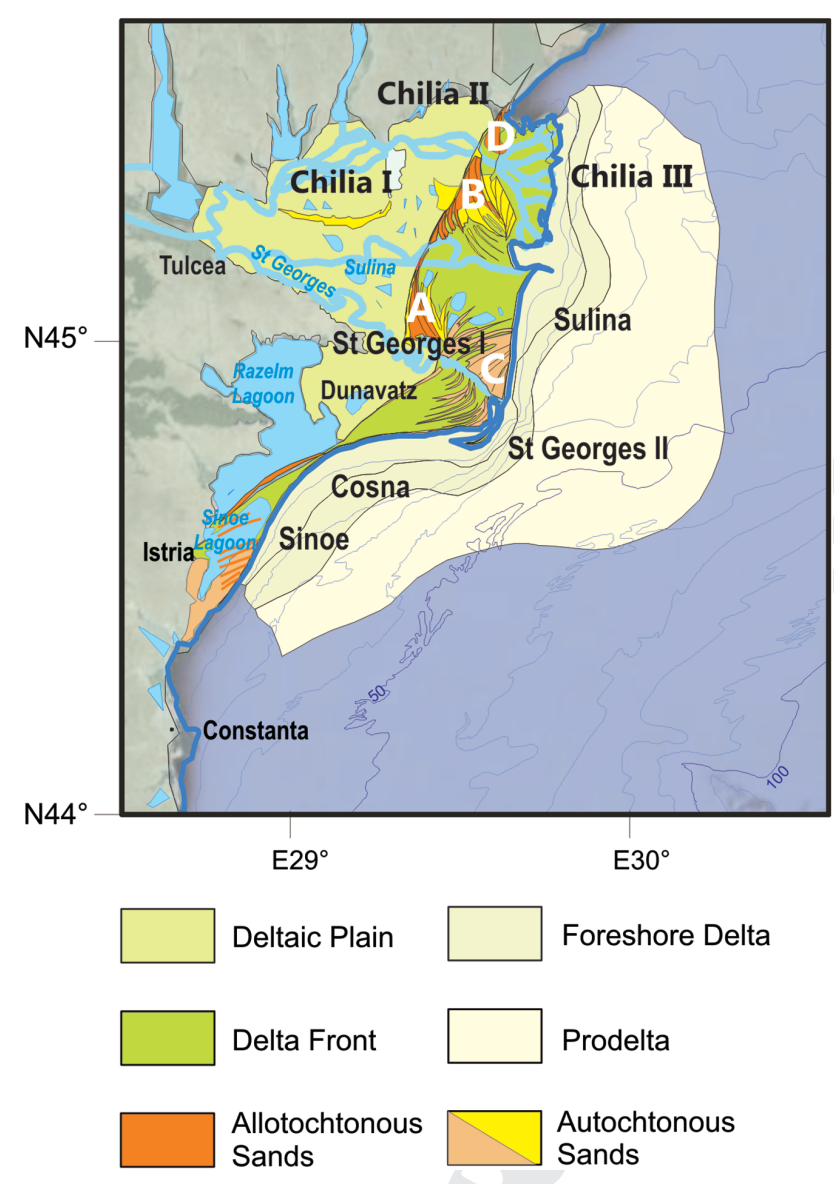

Fig. 17.7 Danube Delta morphology and lobe development sequence. After Panin et al. (1983); Giosan et al. (2006). Postulated locations for Cosna and Sinoe lobes are from Panin et al. (1983).

Major beach ridge plains are (A) Caraorman; (B) Letea; (C)

Saraturile; and (D) Jebrieni. Barrier systems of Zmeica, Lupilor, Istria, and Chituc-segment Razelm-Sinoe lagoons. Location of ancient city of Istria is indicated.

asymmetric morphology (Bhattacharya \& Giosan 2003). Longshore drift obstruction at distributary mouths led to development of an extensive system of beach ridges and plains on the updrift side of these lobes, whereas on the downdrift side, barrier plains developed as a succession of sandy ridges separated by elongated marshes and/or lakes (Giosan et al. 2006). Early interpretations of the pattern of beach ridges established a relative chronology for the open-coast lobes (de Martonne 1931; Zenkovich 1956).

The St. George I was the first lobe formed at the open coast, followed by Sulina; subsequently, the St.
George arm was reactivated, developing a second lobe (Fig. 17.7). Panin (1983) explained the rapid growth of the Sulina lobe as a forced regression during a postulated Black Sea Phanagorian regression around 3000 BP to 2000 BP (Chepalyga 1984). The subsequent reactivation of the St. George branch was attributed to a channel slope increase at the Phanagorian lowstand (Panin 1983). Within the remnant shallow basins of the Danube embayment, the northernmost distributary, the Chilia, developed two successive lacustrine deltas before building into the Black Sea (Fig. 17.7). The Danube Delta Plain extends southward into several generations of bay-mouth barriers (Zmeica, Lupilor, Chituc, Istria), delineating the Razelm-Sinoe lagoon system (Fig. 17.7).

\section{Coastal and Shelf Geomorpho-Dynamics, Erosion, and Accumulation}

The physiographic provinces represented in Figure 17.8 are divided into four main areas: the continental shelf, the continental slope, the glacis, and the bathyal plain.

The continental shelf is well developed in the northwestern part of the basin. The shelf is well marked 140 $\mathrm{km}$ seaward off the Danube mouth, reaching $190 \mathrm{~km}$ westward off Crimea with its width decreasing southerly to almost $40 \mathrm{~km}$ in front of the Bulgarian coast. The continental shelf is nearly absent in the southern part of the Black Sea near the Sakarya canyon. The other parts of the continental shelf are very narrow and reach no more than $20 \mathrm{~km}$ in width, except for the area south of the Sea of Azov where the continental shelf can reach $40 \mathrm{~km}$ in width. The shelf break is located at around a depth of 100 $m$ (Ross \& Degens 1974); in front of the mouth of the Danube it reaches $-120 \mathrm{~m}$ to $-140 \mathrm{~m}$ south of the Viteaz canyon (or Danube canyon), but can be deeper than 170 $\mathrm{m}$ in the northern part of the canyon, probably because of recent tectonic activity.

The continental slope related to the narrow shelf of the south, east and north-east of the Black Sea basin and south of Crimea is relatively steep $(2.5 \%$ according to Ross \& Degens 1974). In contrast to the continental shelf 


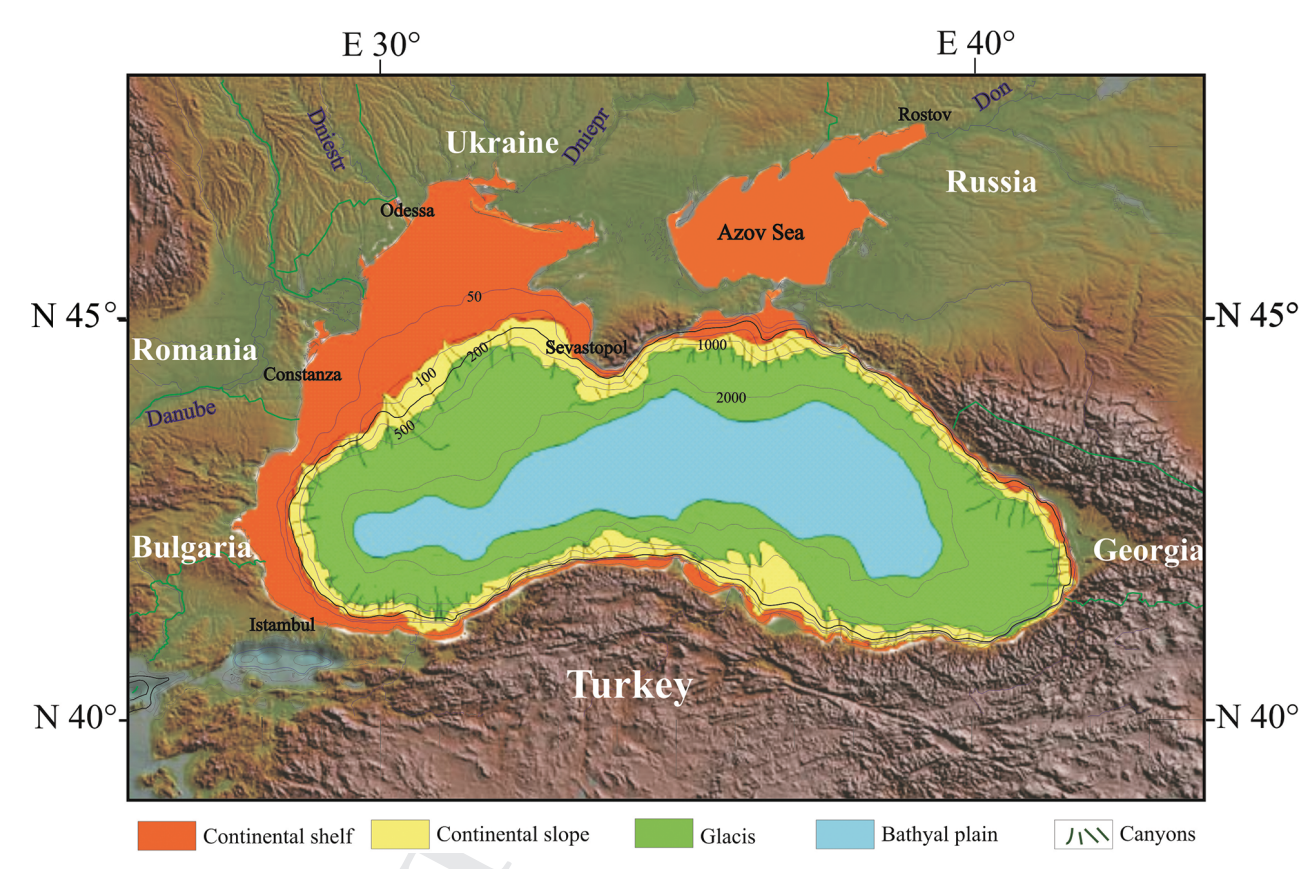

Fig. 17.8 Black Sea physiography. After Panin \& Popescu (2007).

the slope is incised by numerous canyons. Slopes with a lower gradient are situated in the northwestern part of the Black Sea (Danube and Dnieper deep-sea fans) and to the south of the Sea of Azov (Don and Kuban deepsea fans). This parameter is linked to the high rate of sedimentation due to fluvial sediment inflows. In these areas wide canyons are present. The Viteaz canyon and the Dnieper canyons have incised the continental slope, and also the continental shelf landward over a distance of $20 \mathrm{~km}$.

The glacis forms the area along the margin where the terrestrial inflows are deposited. With slopes ranging from $0.1 \%$ to $2.5 \%$, its width is a function of the volume of the inflows. The width reaches its maximum at the Danube and Dnieper fan location.

The bathyal plain is located in the center of the basin showing a slope less than $0.1 \%$ and a maximal depth of $2212 \mathrm{~m}$.

The present-day Black Sea catchment area is dominated by the Danube River and by the rivers from the north of the Black Sea (Dnieper, Dniester, Southern Bug). At the easternmost part of the Black Sea catchment area, the River Don approaches the Volga River. The Kuban is the biggest river bringing water from the Caucasus into the Black Sea via the Sea of Azov. The annual discharge of these six biggest rivers (Danube, Dnieper, Dniester, Southern Bug, Don and Kuban) is $270.3 \mathrm{~km}^{3} /$ year (Fekete et al. 2000). The annual mean contribution of rivers from the Anatolian mountains is only $36 \mathrm{~km}^{3} /$ year and they are not included in the report of Fekete et al. (2000). Most of the river input running into the Caspian Sea is due to the Volga, Ural and Kura (Stolberg et al. 2006). The Aral Sea receives fresh water from the Syr Darya and Amu Darya; their discharge is $60.5 \mathrm{~km}^{3} /$ year (Fekete et al. 2000). The $\mathrm{Ob}$ and Yenisei (at present-day) discharge $965.1 \mathrm{~km}^{3} /$ year of water into the Arctic Ocean.

\section{Conclusion}

The Black Sea is surrounded by high-folded mountain chains, i.e. the Balkanides-Pontides belts to the south/south-west, the Great and Little Caucasus to the east and by the Crimea Mountains to the north, and the Danube Delta lowland is one of its main features. This sea is one of the largest almost-enclosed seas in the world, having roughly an oval shape. The Black Sea is locked in between the southernmost tip of the Crimea 
and Cape Kerempe on the Turkish coast, and is connected to the Mediterranean Sea through the Istanbul-Canakkale (Bosporus-Dardanelles) straits to the west and the Sea of Azov through the Taman-Kerch Strait to the north. Such a physiography is inherited from a peculiar pattern of previous specific sea-level fluctuations. The updated results obtained from oceanographic surveys carried out in the Black Sea have led to the proposal of a scenario for the transition of the Black Sea system from a lacustrine to a marine environment.

Aside from the controversy about the conditions of the last reconnection of the Black Sea, these recent syntheses have improved the chronology of the last reconnection, indicating that it occurred around 9000 years ago. This finding shows that the reconnection was not related to catastrophic drainage of the ice-dammed Lake Agassiz. Moreover, now it is possible to confirm that the replacement of lacustrine by marine biota needed almost 1000 years, the time required for the onset of the two-way flow circulation currently observed in the Sea of Marmara gateway. These results also suggest that the level of the isolated Black Sea was below the former Bosporus sill depth. The recent results obtained from pore water analyses (Soulet et al. 2010) suggest that the Black Sea was a freshwater lake prior to its reconnection with the Sea of Marmara and show that microfossils are often tolerant to a wide range of salinities. For example, the taxon that Marret et al. (2004) used as evidence of Black Sea salinity (S. cruciformis), has also been found in modern sediment from the brackish Caspian Sea. Moreover, this taxon shows extreme morphological variability (Wall \& Dale 1974; Mudie et al. 2001). Such variability may be linked to fluctuations in salinity (Dale 1996). However, no clear relationship between the different morphotypes and surface salinity has been established (Kouli et al. 2001; Mudie et al. 2002).

The debate about the effect of possible salinity variations on the probability of human occupation of the Black Sea shelf during the Neolithic does not necessarily determine whether people lived there or not. Farmers have always valued good, flat, alluvial land, and modern artisanal agriculture in the Mediterranean region shows that crops will grow very close to salt water on sheltered coastlines. Thus the proposal that the fresh Black Sea 'Lake' (Ballard et al. 2000; Major et al. 2002b; Ryan et al.
2003) would have allowed coastal farming on exposed shelves is perfectly true, but a brackish or salty Black Sea (e.g. Mudie et al. 2001; Yanko-Hombach et al. 2007) would not have prevented settlement along the Black Sea coast. In either case people could have lived on the shelf, but, up till now, we do not have in situ evidence for such occupation.

If Neolithic farmers did live on the Black Sea shelf, a rapid flooding of the shelf would have accelerated their dispersal onto higher ground over a period of about 30 years. In spite of speculation that such a retreat from rising sea level would have influenced the rate of the spread of agriculture from the Middle East to northwest Europe, the genetic data which have been used to derive the spread of the so-called 'Neolithic Revolution' do not show a perturbation in the region of the Black Sea. The contours showing the 'frontier' or dates of Neolithization were first plotted by Ammerman and Cavalli-Sforza (1984), and have been refined and analyzed by numerous researchers more recently (e.g. Fort 2012), and there is no sign of a significant increase in rate or distortion in the process around the Black Sea. The spread of agriculture is now considered to have been caused proportionately $60 \%$ to $70 \%$ by demographic movement, and $30 \%$ to $40 \%$ by cultural transfer.

The specific sea-level fluctuations encountered in the Black Sea after the LGM allow us to think that early Neolithic populations could have lived near the Black Sea 'Lake' and experienced the rise of water level when this water body reconnected with the Global Ocean. If the level of the Black Sea drew down to a depth of $100 \mathrm{~m}$ below its present level between 14,000 BP and 10,000 $\mathrm{BP}$, it is conceivable that one might find some buried Neolithic or earlier artifacts on the shelf of the Black Sea. Until archaeological remains are found in situ on the sea floor, the question remains unresolved.

\section{References}

Ahmed Benan, C. A. \& Kocurek, G. 2000. Catastrophic flooding of an aeolian dune field: Jurassic Entrada and Todilto Formations, Ghost Ranch, New Mexico, USA. Sedimentology 47:1069-1080.

Aksu, A. E., Hiscott, R. N. \& Yasar, D. 1999. Oscillating Quaternary water levels of the Marmara Sea and 
vigorous outflow into the Aegean Sea from the Marmara Sea-Black Sea drainage corridor. Marine Geology 153:275-302.

Aksu, A. E., Hiscott, R. N., Mudie, P. J. et al. 2002. Persistent Holocene outflow from the Black Sea to the eastern Mediterranean contradicts Noah's Flood hypothesis. GSA Today 12(5):4-9.

Algan, O., Gokasan, E., Gazioglu, C. et al. 2002. A high-resolution seismic study in Sakarya Delta and Submarine Canyon, southern Black Sea shelf. Continental Shelf Research 22:1511-1527.

Algan, O., Ergin, M., Keskin, S. et al. 2007. Sealevel changes during the Late Pleistocene-Holocene on the southern shelves of the Black Sea. In YankoHombach, V., Gilbert, A. S., Panin, N. \& Dolukhanov, P. M. (eds.) The Black Sea Flood Question: Changes in Coastline, Climate, and Human Settlement. pp. 603632. Springer: Dordrecht.

Amante, C. \& Eakins, B. W. 2009. ETOPO1 1 Arcminute global relief model: procedures, data sources and analysis. National Geophysical Data Center: Boulder, Colorado.

Ammerman, A. J. \& Cavalli-Sforza, L. L. 1984. The Neolithic Transition and the Genetics of Populations in Europe. Princeton University Press: Princeton.

Andrusov, N. I., 1893. Sur l'état du bassin de la Mer Noire pendant l'époque pliocène. Akademiia Nauk Saint Petersburg Bulletin 3:437-448.

Arslanov, K. A., Izmaylov, Y. A., Ostrovskiy, A. B., Tertychnyy, N. I. \& Shcheglov, A. P. 1978. Radiometric age of "Karangatian" terraces of the western Caucasus and the Kerch' strait. Doklady Akademii Nauk SSSR [Reports of the Academy of Sciences of the USSR] 226:25-27 (in Russian).

Bahr, A., Lamy, F., Arz, H. \& Wefer, G. 2005. Rapid hydrological and paleoenvironmental changes in the Black Sea during the Late Glacial and Holocene, recorded with trace element and stable isotope data. Paper presented at the $2^{\text {nd }} A S S E M B L A G E$ Workshop. $17^{\text {th }}-19^{\text {th }}$ November 2005 , Hamburg.

Balabanov, I. P. 1984. Change of wave conditions of Black Sea in Holocene. Proceedings of the Academy of USSR Sciences 5:70-81,

Balabanov, I. P. 2007. Holocene sea-level changes of the Black Sea. In Yanko-Hombach, V., Gilbert, A.
S., Panin, N. \& Dolukhanov, P. M. (eds.) The Black Sea Flood Question: Changes in Coastline, Climate, and Human Settlement. pp. 711-730. Springer: Dordrecht.

Ballard, R. D., Coleman, D. F. \& Rosenberg, G. 2000. Further evidence of abrupt Holocene drowning of the Black Sea shelf. Marine Geology 170:253-261.

Bhattacharya, J. P. \& Giosan, L. 2003. Wave-influenced deltas: geomorphological implications for facies reconstruction. Sedimentology 50:187-210.

Chepalyga, A. L. 1984. Inland sea basins. In Velichko, A. A., Wright, H. E. J. \& Barnosky-Cathy C. W. (eds.) Late Quaternary environments of the Soviet Union. pp. 229-247. University of Minnesota Press: Minneapolis.

Chumakov, I. S., 2000. The problem of the MiocenePliocene boundary in the Euxinian region. Stratigraphy and Geological Correlation 8:396-404.

Clauzon, G., Suc, J.-P., Popescu, S.-M. et al. 2005. Influence of Mediterranean sea-level changes on the Dacic Basin (Eastern Paratethys) during the late Neogene: the Mediterranean Lago Mare facies deciphered. Basin Research 17:437-462.

Dale, B. 1996. Dinoflagellate cyst ecology: modelling and geological applications. In Jansonius, J. \& McGregor, D. C. (eds.) Palynology: principles and applications. pp. 1249-1275. American Association of Stratigraphic Palynologists Foundation: Dallas.

De Martonne, E. 1931. Europe Centrale (2 ${ }^{\text {nd }}$ Ed.). Armand Colin: Paris.

Demirbağ, E., Gökasan, E., Oktay, F. Y., Simsek, M. \& Yüce, H. 1999. The last sea level changes in the Black Sea: evidence from the seismic data. Marine Geology 157:249-265.

Dinu, C., Wong, H. K. \& Tambrea, D. 2002. Stratigraphic and tectonic syntheses of the Romanian Black Sea shelf and correlation with major land structures. In Dinu, C. \& Mocanu, V. (eds.) Geology and Tectonics of the Romanian Black Sea Shelf and its Hydrocarbon Potential (BGF vol. 2). pp. 101-117. Bucharest Geoscience Forum: Bucharest.

Fedorov, P. V. 1963. Stratigraphy of Quaternary sediments on the coast of the Crimea and Caucasus and some problems connected with the geological history of the Black Sea. Akademiia Nauk SSSR Geologicheskii Institutii Trudy 88:159 (in Russian). 
Fekete, B. M., Voeroesmarty, C. J. \& Grabs, W. 2000. Global composite runoff fields on observed river discharge and simulated water balances (Report No. 22). Global Runoff Data Centre: Koblenz, Germany.

Finetti, I. R., Bricchi, G., Del Ben, A., Pipan, M. \& Xuan, Z. 1988. Geophysical study of the Black Sea area. In Finetti, I. R. (ed.) Monograph on the Black Sea. Bollettino di Geofisica Teorica e Applicata 30:197-324.

Fort, J. 2012. Synthesis between demic and cultural diffusion in the Neolithic transition in Europe. Proceedings of the National Academy of Sciences 109:18669-18673.

Giosan, L., Donnelly, J. P., Constantinescu, S. et al. 2006. Young Danube delta documents stable Black Sea level since the middle Holocene: Morphodynamic, paleogeographic, and archaeological implications. Geology 34:757-760.

Giosan, L., Filip, F. \& Constatinescu, S. 2009. Was the Black Sea catastrophically flooded in the early Holocene? Quaternary Science Reviews 28:1-6.

Giunta, S., Morigi, C., Negri, A., Guichard, F. \& Lericolais, G. 2007. Holocene biostratigraphy and paleoenvironmental changes in the Black Sea based on calcareous nannoplankton. Marine Micropaleontology 63:91-110.

Görür, N., Çağatay, N. M., Emre, Ö. et al. 2001. Is the abrupt drowning of the Black Sea shelf at $7150 \mathrm{yr} \mathrm{BP} \mathrm{a}$ myth? Marine Geology 176:65-73.

Hiscott, R. N., Aksu, A. E., Mudie, P. J. et al. 2007. A gradual drowning of the southwestern Black Sea shelf: Evidence for a progressive rather than abrupt Holocene reconnection with the eastern Mediterranean Sea through the Marmara Sea Gateway. Quaternary International 167-168:19-34.

Hsü, K. J., Ryan, W. B. F. \& Cita, M. B. 1973. Late Miocene Desiccation of the Mediterranean. Nature 242:240-244.

Ivanov, I. S. \& Avramova, M. 2000. Varna necropolis: the dawn of European civilization. Agat'o: Sofia.

Au: Please provide volume Jensen, J. B., Bennike, O., Witkowski, A., Lemke, W.
and page number.
Kouli, K., Brinkhuis, H. \& Dale, B. 2001. Spiniferites cruciformis: a fresh water dinoflagellate cyst? Review of Palaeobotany and Palynology 113:273-286.

Kvasov, D. D. 1968. Paleohydrology of eastern Europe in late Quaternary time. In Yezhegodnkkh, V., Chetniyakh, D. \& Pamyati, L. S. (eds.) Berga Doklady. pp. 65-81. Izd Nauka: Moscow (in Russian).

Kwiecien, O., Arz, H. W., Lamy, F. et al. 2008. Estimated reservoir ages of the Black Sea since the last glacial. Radiocarbon 50:99-118.

Lericolais, G., Chivas, A. R., Chiocci, F. L. et al. 2004. Rapid transgressions into semi-enclosed basins since the Last Glacial Maximum. In $32^{\text {nd }}$ International Geological Congress Proceedings (Abstract vol. 2). $20^{\text {th }}-$ $27^{\text {th }}$ August 2004, Florence, p. 1124. Electronic version posted on-line on July 20, 2004 @32nd International Geological Congress.

Lericolais, G., Popescu, I., Guichard, F. \& Popescu, S. M. 2007a. A Black Sea lowstand at 8500 yr B.P. indicated by a relict coastal dune system at a depth of $90 \mathrm{~m}$ below sea level. In Harff, J., Hay, W. W., \& Tetzlaff, D. M. (eds.) Coastline Changes: Interrelation of Climate and Geological Processes (Special Paper 426). pp. 171-188. Geological Society of America: Boulder.

Lericolais, G., Popescu, I., Guichard, F., Popescu, S-M. \& Manolakakis, L. 2007b. Water-level fluctuations in the Black Sea since the Last Glacial Maximum. In YankoHombach, V., Gilbert, A. S., Panin, N. \& Dolukhanov, P. M. (eds.) The Black Sea Flood Question: Changes in Coastline, Climate, and Human Settlement. pp. 437452. Springer: Dordrecht.

Lericolais, G., Bulois, C., Gillet, H. \& Guichard, F. 2009. High frequency sea level fluctuations recorded in the Black Sea since the LGM. Global and Planetary Change 66:65-75.

Lericolais, G., Guichard, F., Morigi, C., Minereau, A., Popescu, I. \& Radan, S. 2010. A post Younger Dryas Black Sea regression identified from sequence stratigraphy correlated to core analysis and dating. Quaternary International 225:199-209.

Lericolais, G., Guichard, F., Morigi, C. et al. 2011. Assessment of the Black Sea water-level fluctuations since the Last Glacial Maximum. In Buynevich, I. V., Yanko-Hombach, V., Gilbert, A. S. \& Martin, R. E.

Kerr, R. A. 2000. A victim of the Black Sea Flood found. Science 289:2021. 
(eds) Geology and Geoarchaeology of the Black Sea Region: Beyond the Flood Hypothesis (Special Paper 473). pp. 33-50. Geological Society of America: Boulder.

Lericolais, G., Popescu, I, Bourget, J. et al. 2012. The "Sink" of the Danube River Basin: The Distal Danube Deep-Sea Fan. In Rosen, N. C. et al. (eds.) New Understanding of the Petroleum Systems of Continental Margins of the World (32 $2^{\text {nd }}$ Annual GCSSEPM Foundation Annual Bob F. Perkins Research Conference Proceedings. (vol. 32). $2^{\text {nd }}-5^{\text {th }}$ December 2012, Houston (Texas), pp. 701-735.

Lericolais, G., Bourget, J., Popescu, I. et al. 2013. Late Quaternary deep-sea sedimentation in the western Black Sea: New insights from recent coring and seismic data in the deep basin. Global and Planetary Change 103:232-247.

Letouzey, J., Gonnard, R., Khristchev, K., Montadert, L. \& Dorkel, A. 1978. Black Sea: Geological setting and recent deposits distribution from seismic reflection data. In Ross, D. A. et al. Initial Reports of the Deep Sea Drilling Project (vol. 42). pp. 1077-1084. USGPO: Washington.

Lordkipanidze, D., de Leon, M. S. P., Margvelashvili, A. et al. 2013. A complete skull from Dmanisi, Georgia, and the evolutionary biology of Early Homo. Science 342:326-331.

Loubrieu, B., Mascle, J., Benkhelil, J. et al. 2008. Morpho-bathymetry of the Mediterranean Sea. In CIESM (ed.) CIESM Maps. Ifremer Medimap Group: Monaco.

Major, C., Goldstein, S. L., Ryan, W., Piotrowski, A. \& Lericolais, G. 2002a. Climate change in the black sea region through termination I from $\mathrm{Sr}$ and $\mathrm{O}$ isotopes. Geochimica Et Cosmochimica Acta, 66(15A):A476-A476.

Major, C., Ryan, W., Lericolais, G. \& Hajdas, I. 2002 b. Constraints on Black Sea outflow to the Sea of Marmara during the last glacial-interglacial transition. Marine Geology 190:19-34.

Major, C. O., Goldstein, S. L., Ryan, W. B. F., Lericolais, G., Piotrowski, A. M. \& Hajdas, I. 2006. The coevolution of Black Sea level and composition through the last deglaciation and its paleoclimatic significance. Quaternary Science Reviews 25:2031-2047.
Marret, F., Leroy, S., Chalié, F. \& Françoise F. 2004. New organic-walled dinoflagellate cysts from recent sediments of Central Asian seas. Review of Palaeobotany and Palynology 129:1-20.

Mărunţeanu, M. 1992. Distribution of the calcareous nannofossils in the intra- and extra-Carpathian areas of Romania. Knihovnicka Zemniho Plynu Nafty 14b:247261

Meulermamp, J. E. \& Sissingh, W. 2003. Tertiary palaeogeography and tectonostratigraphic evolution of the Northern and Southern Peri-Tethys platforms and the intermediate domains of the African-Eurasian convergent plate boundary zone. Palaeogeography, Palaeoclimatology, Palaeoecology 196:209-228.

Mudie, P. J., Aksu, A. E. \& Yasar, D. 2001. Late Quaternary dinoflagellate cysts from the Black, Marmara and Aegean seas: variations in assemblages, morphology and paleosalinity. Marine Micropaleontology 43:155178.

Mudie, P. J., Rochon, A., Aksu, A. E. \& Gillespie, H. 2002. Dinoflagellate cysts, freshwater algae and fungal spores as salinity indicators in Late Quaternary cores from Marmara and Black seas. Marine Geology 190:203-231.

Muratov, V. M., Ostrovskiy, A. B. \& Fridenberg, E. O. 1974. Quaternary stratigraphy and palaeogeography on the Black Sea coast of Western Caucasus. Boreas 3:4960.

Nevesskiy, E. N. 1961. Postglacial transgressions of the Black Sea. Doklady Akademii Nauk SSSR 137:667-670 (in Russian).

Nicholas, W. A., Chivas, A. R., Murray-Wallace, C. V. \& Fink, D. 2011. Prompt transgression and gradual salinisation of the Black Sea during the early Holocene constrained by amino acid racemization and radiocarbon dating. Quaternary Science Reviews 30:37693790.

Okay, A. I., Celal Sengör, A. M. \& Görür, N. 1994. Kinematic history of the opening of the Black Sea and its effect on the surrounding regions. Geology 22:267270.

Ostrovskiy, A. B., Izmaylov, Y. A., Sccheglo, A. P., Arslanov, S. A. \& Shchelinskiy, V. Y. 1977. New data on the stratigraphy and geochronology of Pleistocene 
marine terraces of the Black Sea coast, Caucasus, and Kerch-Taman region. In Kaplin, P. A. \& Shcherbakov, F. A. (eds.) Paleogeography and Deposits of the Pleistocene of the Southern seas of the USSR. pp. 61-99. NaukaPress: Moscow (in Russian).

Panin, N. 1983. Black Sea coastline changes in the last 10,000 years: a new attempt at identifying the Danube mouths as described by the ancients. Dacia 27:175-184.

Panin, N. 1996. Danube Delta: genesis, evolution, geological setting and sedimentology. Geo-Eco-Marina 1:7-23.

Panin, N. \& Popescu, I. 2007. The northwestern Black Sea: climatic and sea level changes in the Upper Quaternary. In Yanko-Hombach, V., Gilbert, A. S., Panin, N. \& Dolukhanov, P. M. (eds.) The Black Sea Flood Question: Changes in Coastline, Climate, and Human Settlement. pp. 387-404. Springer: Dordrecht.

Panin, N., Panin, S., Herz, N. \& Noakes, J. E. 1983. Radiocarbon dating of Danube Delta deposits. Quaternary Research 19:249-255.

Papaianopol, I. \& Marinescu, F. 1995. Lithostratigraphy and age of Neogene deposits on the Moesian Platform, between Olt and Danube Rivers. Romanian Journal of Stratigraphy 76:67-70.

Papp, A., Cicha, I., Rögl, F., Senes, J., Steininger, F. \& Baldi, T. 1974. Principes de la subdivision stratigraphique de la Paratéthys Centrale. Mémoire du BRGM 78:767-774.

Pirazzoli, P. A. (ed.) 1991. World Atlas of Holocene SeaLevel Changes. Elsevier Oceanography Series, (vol. 58). Elsevier: Amsterdam.

Popescu, I. \& Lericolais, G. 2009. An atypical sediment failure event in the Danube deep-sea fan (Black Sea). In Chiocci, F. L. (ed.) International Conference on Seafloor Mapping for Geohazard Assessment. $11^{\text {th }}-13^{\text {th }}$ May 2009, Forio d'Ischia (Italy), pp. 182-185.

Popescu, I., Lericolais, G., Panin, N., Wong, H. K. \& Droz, L. 2001. Late Quaternary channel avulsions on the Danube deep-sea fan, Black Sea. Marine Geology 179:25-37.

Popescu, I., Lericolais, G., Panin, N., Normand, A., Dinu, C. \& Le Drezen, E. 2004. The Danube submarine canyon (Black Sea): morphology and sedimentary processes. Marine Geology 206:249-265.
Popescu, S. M. 2004. Sea-level changes in the Black Sea region since $14 \mathrm{ka}$ BP. In $32^{\text {nd }}$ International Geological Congress Proceedings (Abstract vol. 2). $20^{\text {th }}-27^{\text {th }}$ August 2004, Florence, p. 1426. Electronic version posted on-line on July 20, 2004 (C)32nd International Geological Congress.

Posamentier, H. W. \& Vail, P. R. 1988. Eustatic controls on clastic deposition II - sequence and systems tracts models. In Wilgus, W. K., Hastings, B. S., Posamentier, H. et al. (eds.) Sea-level changes - An integrated approach. pp. 125-154. SEPM: Tulsa.

Rögl, F. 1998. Paleogeographic considerations for Mediterranean and Paratethys seaways (Oligocene to Miocene). Annalen des Naturhistorischen Museums in Wein 99(A):279-310.

Rögl, F. 1999. Mediterranean and Paratethys. Facts and hypotheses of an Oligocene to Miocene paleogeography (short overview). Geologica Carpathica-Bratislava 50:339-349.

Ross, D. A. \& Degens, E. T. 1974. Recent sediments of the Black Sea. In Degens, E. T. \& Ross, D. A. (eds.) The Black Sea - Geology, Chemistry and Biology. pp. 183-199. American Association of Petroleum Geologists: Tulsa.

Ryan, W. B. F. 2007. Status of the Black Sea flood hypothesis. In Yanko-Hombach, V., Gilbert, A. S., Panin, N. \& Dolukhanov, P. M. (eds.) The Black Sea Flood Question: Changes in Coastline, Climate, and Human Settlement. pp. 63-88. Springer: Dordrecht.

Ryan, W. B. F., Pitman, W. C., Major, C. O. et al. 1997. An abrupt drowning of the Black Sea shelf. Marine Geology 138:119-126.

Ryan, W. B. F., Major, C. O., Lericolais, G. \& Goldstein, S. L. 2003. Catastrophic flooding of the Black Sea. Annual Review of Earth and Planetary Sciences 31:525554.

Ryan, W. B. F., Carbotte, S. M., Coplan, J. O. et al. 2009. Global Multi-Resolution Topography synthesis. Geochemistry, Geophysics, Geosystems 10:Q03014.

Shimkus, K. M., Evsyukov, Y. D. \& Solovjeva, R. N. 1980. Submarine terraces of the lower shelf zone and their nature. In Malovitsky, Y. P. \& Shimkus, K. M. (eds.) Geological and Geophysical Studies of the PreOceanic Zone. pp. 81-92. P.P. Shirshov Institute of Oceanology: Moscow (in Russian). 
Soulet, G., Delaygue, G., Vallet-Coulomb, C. et al. 2010. Glacial hydrologic conditions in the Black Sea reconstructed using geochemical pore water profiles. Earth and Planetary Science Letters 296:57-66.

Soulet, G., Ménot, G., Garreta, V. et al. 2011a. Black Sea "Lake" reservoir age evolution since the Last Glacial - Hydrologic and climatic implications. Earth and Planetary Science Letters 308:245-258.

Soulet, G., Ménot, G., Lericolais, G. \& Bard, E. 2011b. A revised calendar age for the last reconnection of the Black Sea to the global ocean. Quaternary Science Reviews 30:1019-1026.

Soulet, G., Ménot, G., Bayon, G. et al. 2013. Abrupt drainage cycles of the Fennoscandian Ice Sheet. Proceedings of the National Academy of Sciences (U.S.A.) 110:6682-6687.

Steininger, F. F. \& Papp, A. 1979. Current biostratigraphic and radiometric correlations of Late Miocene Central Paratethys stages (Sarmatian s.str., Pannonian s.str., and Pontian) and Mediterranean stages (Tortonian and Messinian) and the Messinian Event in the Paratethys. Newsletters on Stratigraphy 8:100-110.

Stolberg, F., Borysova, O., Mitrofanov, I., Barannik, V. \& Eghtesadi, P. 2006. GIWA Regional Assessment 23Caspian Sea. University of Kalmar: Sweden.

Strechie, C., André, F., Jelinowska, A. et al. 2002. Magnetic minerals as indicators of major environmental change in holocene black sea sediments: preliminary results. Physics and Chemistry of the Earth, Parts $A / B / C$ 27:1363-1370.

Uchupi, E. \& Ross, D. A. 2000. Early Holocene Marine Flooding of the Black Sea. Quaternary Research 54:6871.

Wall, D. \& Dale, B., 1974. Dinoflagellates in the late Quaternary deep-water sediments of the Black Sea. In Degens, E. T. \& Ross, D. A. (eds.) The Black Sea Geology, Chemistry and Biology. pp. 364-380. American Association of Petroleum Geologists: Tulsa.

Yanko, V. V. 1990. Stratigraphy and paleogeography of marine Pleistocene and Holocene deposits of the southern seas of the USSR. Memorie Societa Geologica Italiana 44:167-187.

Yanko-Hombach, V., Gilbert, A. S., Panin, N. \& Dolukhanov, P. M. (eds.) 2007. The Black Sea Flood Question: Changes in Coastline, Climate, and Human Settlement. Springer: Dordrecht.

Yaranov, D. 1938. Essai sur le climat de la Bulgarie pendant le pliocène et le quaternaire (contribution à l'étude paléoclimatologique de la région méditerranéenne). Bulletin de l'académie bulgare des sciences 53:1-29.

Zenkovich, V. P. 1956. Zagadka Dunaiskoi Delty. Priroda 45:86-90 (in Russian).

Zonenshain, L. P. \& Pichon, X. 1986. Deep basins of the Black Sea and Caspian Sea as remnants of Mesozoic back-arc basins. Tectonophysics 123:181-211. 
